$\begin{array}{ll}\text { Australian rules } & \begin{array}{l}\text { Space suit } \\ \text { Bush plumps for } \\ \text { Michael Griffin } \\ \text { to head NASA } \\ \text { p261 }\end{array} \\ \text { A rugby team } \\ \text { tailors training } \\ \text { with genetic tests } \\ \text { p260 }\end{array}$

\title{
Indian regulations fail to monitor growing stem-cell use in clinics
}

\section{K. S. Jayaraman, New Delhi}

Two Indian government departments that have fought for years over who should control stem-cell research are finally negotiating a single set of guidelines for clinical practice.

The move has been driven by the mushrooming of clinics, both public and private, that claim to use stem cells to treat a wide range of diseases. The cells come from bone marrow, umbilical-cord blood and even human embryonic sources. Yet there is no supervision of procedures for preparing stem cells or clinical follow-up, says Vasantha Muthuswami, head of basic medical sciences at the Indian Council of Medical Research (ICMR) in New Delhi.

"We want to promote stem-cell technology but not in this scandalous way," Muthuswami says. Basic research to prove the efficacy and safety of procedures has not been completed anywhere in the world, she points out.

In 2002, the ICMR, which belongs to the health ministry, announced a policy that permitted therapeutic cloning and encouraged stem-cell research. But the previous year the Department of Biotechnology (DBT), which belongs to the science ministry, had also issued guidelines, and some clinics had exploited these to begin clinical treatments.

The ICMR has received numerous applications for funding in recent months, some of which are startlingly naive, says Muthuswami. But it has also received notification of ongoing clinical research, seemingly approved by the DBT and local ethical committees, and she suspects that at least one of these involves stem cells derived from human embryos. Four institutions have informed the ICMR that they are planning to start transplants of human embryonic stem cells. Private blood banks are being established to supply therapies using cord-blood stem cells, she adds. And many private clinics that are offering stem-cell therapy have never contacted the ICMR.

No one has a clear idea of what clinical studies are being carried out where, and how they are being evaluated, admit the ICMR and the DBT. Now the head of the DBT, Maharaj Bhan, who took office last year, has

Moving too fast: the All India Institute of Medical Sciences is already using stem cells to treat stroke.

asked for a meeting with the ICMR to agree common guidelines to ensure clear supervision and appropriate controls. And on 5 March at a meeting in Hyderabad, the head of the DBT's stem-cell task force, Dorairajan Balasubramanian, announced plans to conduct a series of workshops to familiarize doctors with rules on good clinical practice.

\section{Hard sell}

Hyderabad seems to be a centre for stemcell medicine - the privately owned L. V. Prasad Eye Institute in Hyderabad pioneered techniques as early as 2001. The institute says it has used transplanted stem cells to treat more than 240 patients with damaged corneas. Two other private hospitals in Hyderabad are using stem-cell therapy to treat damaged heart muscle, and plans are in place in other hospitals and clinics in the city to use stem cells to regenerate the liver in cirrhosis sufferers and the pancreas in diabetics.

One of the biggest shocks has been last month's announcement in the Times of India that a top heart surgeon at New Delhi's All India Institute of Medical Sciences (AIIMS) has used stem cells derived from bone marrow to treat 35 patients during bypass surgery. The surgeon, Panangipalli Venugopal, said in the newspaper report that he and his colleagues had also administered stem cells to patients with cerebral palsy, muscular dystrophy and stroke. Venugopal, who has not published his work in a peerreviewed scientific journal, was not available to comment.

"We are only a block away from AIIMS and we did not know this was happening there," says Muthuswami. "If the nation's premier medical institute did not ask our permission for such therapy, how can we blame private clinics for what they do?"

The quality of cells being used in therapy is of major concern, as is the failure of clinicians to understand stem-cell biology. "A lot of basic research is needed and the safety and efficacy of therapy must be experimentally proven in animals," Polani Seshagiri, a stemcell biologist at the Bangalore-based Indian Institute of Science, told Nature. "The cells we put in the body must be of clinical grade, and how many clinicians ensure this?"

Muthuswami says that the planned guidelines will not stop research but will ensure that there are sufficient checks and controls on clinical practice. "It will no longer be a free-for-all." 